\title{
発表場面における“あがり”
}

\author{
一唾液中コルチゾールと感情の変化の検討一 \\ ○慶野友祐 阿部恒之 \\ (東北大学大学院文学研究科心理学講座)
}

Key words：“あがり”, 唾液中コルチゾール, 緊張覚醒

目的

多くの人が，日常生活の場面において “あがる”ことを経験す る。有光・今田 (1999) は, 我々が日常語として用いる “あがり” を，心理学的概念として定義し，“あがり”状態質問紙を作成した。 それ以降, “あがり”については, 社会心理学分野を中心に検計が 行われてきたが, “あがり”に伴う生理反応については, 未だ十分 な検討がなされていない。特に，内分泌系の反応については，扱 った研究が殆ど存在しない。

Dickerson (2004) の self-preservation theoryによれば, HPA 系の指標である唾液中コルチゾールは社会的評価に関わり，かつ コントロール不可能な状況において最も多く分泌される。“あが り”が, 社会的評価を伴う状況において喚起される（有光，2005） ことを踏まえると, “あがり”によって唾液中コルチゾールの分泌 が高進されることが推測される。

一方，阿部（2002）は，様々な場面の唾液中コルチゾールの挙 動を検討し，その上昇が，緊張感などの特異な感情経験と結びつ いているのではなく，考えること，すなわち脳活動によって多量 に消費されるグルコースの維持という, 生理的な要求に基づくも のであることを指摘している。

“あがり”という現象を, 内分泌系の挙動を含めて, 総合的に 理解するための第一歩として, 本研究では, 発表場面における“あ がり” の程度, 唾液中コルチゾール濃度, 感情経験を測定し、こ れらの指標の挙動・関連性を検討する。

\section{方 法}

口参加者

東北大学の大学院生 6 名 (平均年齢 : 23.0 歳 $\cdot S D: 1.55$ )。

\section{口指標}

(1) “あがり” : 有光 · 今田 (1999) による, “あがり” 状態質問紙 の 12 項目を使用した。12 項目の評定値を合計し, “あがり” 得点 とした。

(2)感情状態: 織田・高野・阿部・菊池（2015）による，感情・覚 醒・チェックリスト (Development of the Emotion and Arousal Checklist；EACL）を使用した。33 の形容詞（悲しい，落ち着か ないなど) について，6段階評定を行った。EACLは, “恐怖”, “喜 び”など 9 因子から構成されるが, 本研究ではその中でも特に, “緊張覚醒”因子項目に着目した。

(3)唾液中コルチゾール：唾液をサリベットによって採取し，遠心 分離後冷凍保存し, 解凍して高速液体クロマトグラフ (資生堂製) によって分析を行った。

\section{口手続き}

大学院生が研究発表を行う演習形式の授業 (16:20-17:50)におい て, 発表直前, 発表直後, 発表 1 時間後の計 3 回, “あがり” 状態, 感情状態，および唾液中コルチゾールの測定を行った。また，発 表日から 1 2 週後の, 発表など特別な出来事の無い日（通常日） にも，同時刻に 3 回の測定を行った。

\section{結 果}

“あがり”得点について, 3 (測定タイミング : 発表直前, 発表 直後, 発表 1 時間後） $\times 2$ (測定日：発表日, 通常日）の 2 要因 参加者内分散分析を実施した。その結果, 測定日の主効果 $(F(1,5)$ $\left.=43.67, \quad \eta^{2}=.60, p<.01\right)$ が認められ, 通常日よりも発表日の得 点が高かった (図 1)。

唾液中コルチゾール濃度について，同様の分散分析を行ったと ころ, 測定日の主効果 $\left(F(1,5)=7.36, \eta^{2}=.90, p<.05\right)$ が認 められ，通常日よりも発表日の濃度が高かった（図 2）。

さらに, “あがり” 得点と唾液中コルチゾール濃度の間には有 意な正の相関が認められた $(r=.419, p<.05) 。 一$ 方, EACL の緊 張覚醒+得点と唾液中コルチゾール濃度の間には相関は認められ なかった $(r=.322, p>05)$ 。
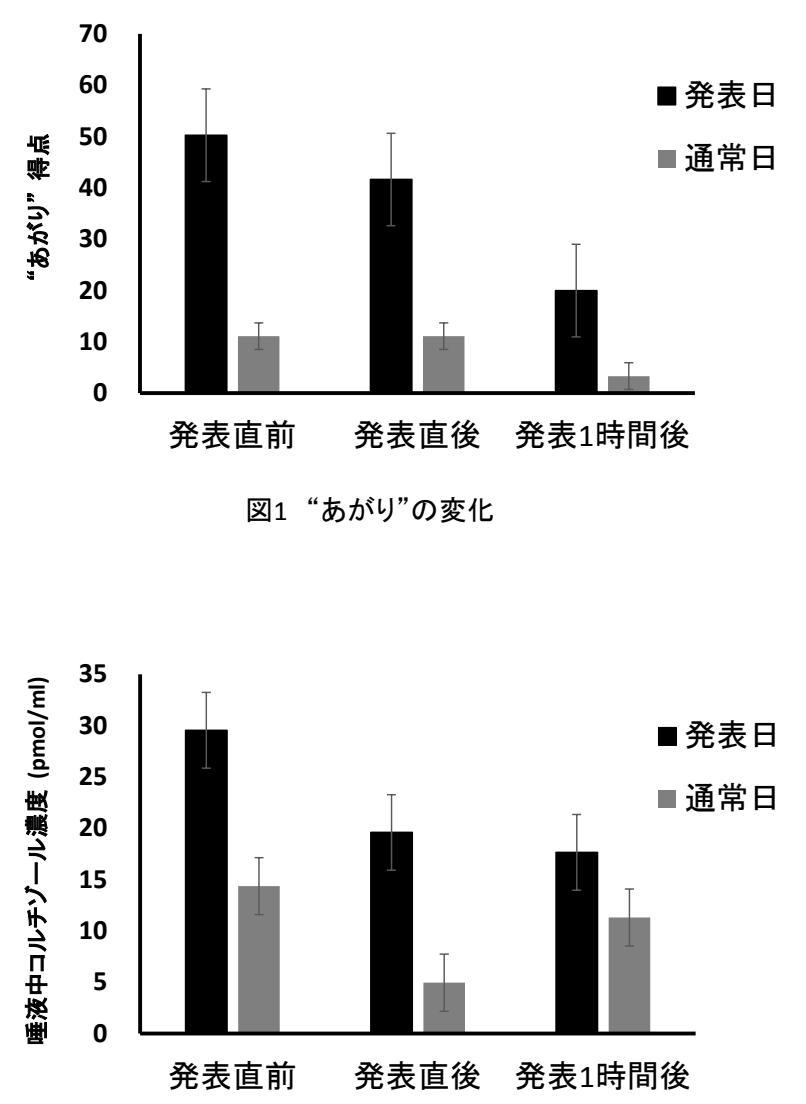

図2 唾液中コルチゾール濃度の変化

\section{考 察}

通常日より発表日において, “あがり”得点が高かった。この ことから，当研究が対象とした発表場面は，“あがり”を喚起する 状況であることが確認された。唾液中コルチゾール濃度について も同様に, 発表日に高まることが確認された。

緊張感と唾液中コルチゾールの間には, 有意な相関が認められ なかった。これは, 阿部 (2002) の結果と一致している。その一 方で, “あがり” 得点之唾液中コルチゾールの間に正の有意な相関 が認められたことは, “あがり”が, 緊張感とは異なる, 固有の特 徵を有する感情経験だという可能性を示唆するものである。

(Yusuke KEINO, Tsuneyuki ABE) 